\title{
P03.16. Student centered learning to practice patient-centered integrative medicine: the ESPRI2T approach
}

\author{
C Scheffer", D Tauschel, D Cysarz, G Lutz, M Neumann, F Edelhäuser \\ From International Research Congress on Integrative Medicine and Health 2012 \\ Portland, Oregon, USA. 15-18 May 2012
}

\section{Purpose}

In 2004, the Integrated Curriculum for Anthroposophic Medicine (ICURAM) was launched to educate medical students in patient-centered integrative care and to develop appropriate didactic formats for that purpose.

\section{Methods}

A six-year program was developed with longitudinally integrated modules complementing the regular medical curriculum. The educational strategy behind the program is the ESPRI2T approach. It combines Explorative learning, Supported participation, Patient-based learning, Reflective practice, Integrated Learning, Integrative Approach and Team-based learning. Student participation was assessed based on credit points achieved per year (ctp/y) through the ICURAM ( $1 \mathrm{ctp}=25-30$ hour workload). The impact of the new and innovational didactic formats was evaluated by examining those adopted for use outside the ICURAM.

\section{Results}

Fifty-five percent of 412 medical students participated in the program: $16 \%$ full participation $(>4 \mathrm{ctp} / \mathrm{y}), 18 \%$ partial participation (1-3.99 ctp/y) and 22\% occasional participation $(0.25-0.99 \mathrm{ctp} / \mathrm{y})$. Five didactic innovations were adopted by the medical school for use in the regular medical curriculum.

\section{Conclusion}

The ICURAM program has been widely accepted and appreciated by both medical students and the medical school. The combination of patient-centeredness and student-centeredness as in the ESPRI2T approach presents a promising means of educating students in patient-centered integrative care.

Published: 12 June 2012

doi:10.1186/1472-6882-12-S1-P269

Cite this article as: Scheffer et al.: P03.16. Student centered learning to practice patient-centered integrative medicine: the ESPRI2T approach. BMC Complementary and Alternative Medicine 2012 12(Suppl 1):P269.
Submit your next manuscript to BioMed Central and take full advantage of:

- Convenient online submission

- Thorough peer review

- No space constraints or color figure charges

- Immediate publication on acceptance

- Inclusion in PubMed, CAS, Scopus and Google Scholar

- Research which is freely available for redistribution
() Biomed Central
University of Witten/Herdecke, ICURAM, Witten, Germany 